\title{
ONESNAŽENOST LEDENIKA BALTORO KOT POSLEDICA TURISTIČNE DEJAVNOSTI
}

\author{
Irena Mrak \\ Oddelek za geografijo, FF, Univerza v Ljubljani, Aškerčeva 2, \\ SI- I000 Ljubljana, Slovenija \\ e-mail: irena.mrak@siol.net
}

Izvirni znanstveni članek

COBISS 1.01

\section{Izvleček}

Množične turistične aktivnosti v visokogorju povsod po svetu že kažejo negativne okoljske učinke. Na izbranem območju preučevanja, ledeniku Baltoro (Karakorum, Pakistan), je to predvsem pogled in/ali vzpon na drugo najvišjo goro na svetu - K2 (8611m) in okoliške gore. S terenskim delom na območju ledenika Baltoro smo ugotavljali vire onesnaževanja in stopnjo onesnaženosti širšega območja ledenika.

Ključne besede: visokogorski turizem, okoljski pritiski in učinki turizma, ledenik Baltoro, Karakorum, Pakistan.

\section{POLLUTION ON THE BALTORO GLACIER AS A CONSEQUENCE OF TOURISM}

\begin{abstract}
Mass tourism in the world's high mountain areas is already having negative environmental impacts. In the case study area of the Baltoro Glacier (Karakorum Mountains, Pakistan) the main motive is a view or even an ascent of $\mathrm{K} 2(8611 \mathrm{~m})$ as well as the surrounding high mountains. The field work carried out was dedicated to pollution sources in the area, as well as to the pollution rate of the wider Baltoro Glacier area.
\end{abstract}

Key words: high mountain tourism, environmental pressures and impacts of tourism, Baltoro Glacier, Karakorum Mountains, Pakistan. 


\section{UVOD}

Visokogorje je zaradi specifičnih geografskih razmer dolga stoletja ostajalo nenaseljeno in človek ga je večinoma le občasno obiskoval. Gospodarska raba je bila vezana predvsem na rudarjenje ter planinsko pašništvo. S pojavom turizma v visokogorju so se učinki človeka okrepili in predvsem prostorsko razširili do te mere, da so postali opazni, moteči in na nekaterih območjih okoljsko nesprejemljivi. S hitrim razvojem turizma v gorskih območjih se intenzivnost pritiskov in učinkov hitro povečuje (Newsome et al., 2002). Največ pozornosti namenjamo okoljskim vplivom in učinkom turizma, ki so večplastni, saj se odražajo kot pritiski na naravno okolje v najširšem smislu, kot onesnaževanje glavnih okoljskih sestavin (relief, prst, voda, zrak) in kot negativni vplivi in učinki na naravno rastlinstvo in živalstvo (Wong, 2004).

Z vse bolj množičnim obiskom visokogorja ter razvojem različnih, predvsem športnih aktivnosti, so nekatera visokogorska območja postala degradirana ali vsaj resno ogrožena. Dosedanje raziskave ugotavljajo negativne okoljske vplive turizma in rekreacije nasploh, pri čemer izpostavljajo zmanjševanje obsega in kakovosti naravnih virov, negativni vpliv na vode, predvsem na pitno vodo, zmanjševanje virov hrane, energije in drugih surovin ter degradacijo površja. Negativni okoljski vplivi se kažejo še v onesnaževanju zraka z izpušnimi plini in hrupom, onesnaževanju s trdnimi odpadki in eroziji poti, ki ogroža prst ter posledično matično osnovo, vodo pa ogrožajo odpadne vode, olja in različne kemične snovi. Posebej je potrebno izpostaviti tudi vizualno onesnaženje kot posledico gradnje turistične in rekreacijske infrastrukture, ki je v konfliktu z okoljem (UNEP, 2007).

Turizem v gorah negativno vpliva predvsem na živalstvo in rastlinstvo (motenje živali, vpliv na vegetacijo), povzroča erozijo pohodniških poti, negativno vpliva na vodo in zrak. Turizem ima lahko tudi pozitivne učinke v gorskih območjih, ki so v večji meri vezani na tamkajšnje prebivalce. Tako velja med pozitivnimi učinki izpostaviti izboljševanje splošne infrastrukture, boljše ekonomske priložnosti za prebivalce gorskih območij ter ustanavljanje zavarovanih območij, ki nastanejo kot posledica izjemnih geografskih značilnosti gorske pokrajine (Newsome et al., 2002).

Območje ledenika Baltoro v pogorju Karakorum se sooča z množičnim obiskom turistov v poletnem času od petdesetih let 20. stoletja dalje. Turizem predstavlja enega glavnih virov zaslužka za domačine, ki živijo v bližini ledenika (Ives, 2004), prav tako pa pomembno prispeva v državni proračun Pakistana, saj so že nekaj desetletij uveljavljene visoke pristojbine za gorske vrhove in dovoljenja za vstop na območje ledenika. Negativni in pozitivni učinki turizma na širšem območju ledenika so dejstvo, pri čemer negativni učinki prevladujejo na ožjem območju ledenika, pozitivni (predvsem ekonomski in socialni) pa na širšem območju doline Šigar in celotne province Baltistan.

\section{OPREDELITEV VISOKOGORJA}

Opredelitev pojma »visokogorje« v svetovnih gorskih območjih ni poenotena. Tako Geografski terminološki slovar opredeljuje visokogorje kot »gorski svet, ki s svojimi vrhovi sega nad zgornjo gozdno mejo« (Kladnik et al., 2005). Geografski riječnik (Cvitanović, 2002) 
podrobneje opiše gorsko območje, in sicer so to »izstopajoča in prostrana reliefno vzpeta območja, kjer so absolutne višine višje od $1000 \mathrm{~m}$; so masivna in razdrapana, obkrožena s širokim nižjim območjem. Po višini se običajno delijo na nižja $(1000-1500 \mathrm{~m})$, srednja (1500 $\mathrm{m}-2000 \mathrm{~m}$ ) in visoka (nad $2000 \mathrm{~m}$ ). Vrhovi so običajno goli in izpostavljeni preperevanju, pobočja so strma in erozijsko preoblikovana, doline so globoke, s strmimi pobočji. V višjih gorah pod ločnico večnega snega in ledu prevladuje gozd, doline in uravnave služijo za pašništvo, značilno je še gozdarstvo; promet je otežen, zato se gradijo predori in ceste preko prelazov, doline se premoščajo z viadukti; v novejšem času se gradijo žičnice, vedno bolj pa je pomemben zimski turizem« (Cvitanović, 2002).

Glede na geografske značilnosti in hkrati razlike svetovnih visokogorskih območij je težko postaviti enotno definicijo visokogorja, lahko pa opredelimo ključne sestavne dele. Govorimo lahko o stabilnem in labilnem delu pri čemer v stabilni del sodijo naravnogeografski faktorji (in njihove značilnosti), ki so tipični za vsa visokogorska območja (relief in gorsko podnebje) ter človekove dejavnosti, ki so prisotne v teh območjih (pašništvo, pohodništvo, alpinizem, raziskovanje). Labilni del, ki razlikuje posamezna visokogorska območja med seboj, vključuje geografsko širino, nadmorsko višino, klimatsko gozdno mejo ter zgornjo višino stalne poselitve. Zlasti labilni del definicije omogoča opredelitev visokogorskih območij v vseh svetovnih gorstvih, kjer opredelitev zgolj na podlagi npr. nadmorske višine ali gorskega podnebja ne bi zadostovala. Človek praviloma v visokogorju ni stalno prisoten, zato je zgornja meja stalne poselitve prav tako ena od labilnih komponent splošne definicije. Predvsem $\mathrm{z}$ razvojem turizma se prisotnost človeka $\mathrm{v}$ teh območjih časovno podaljšuje, ob tem pa se stopnjujejo tudi njegovi okoljski vplivi in učinki.

Slika 1: Splošna definicija visokogorja

Figure 1: The definition of high mountain areas

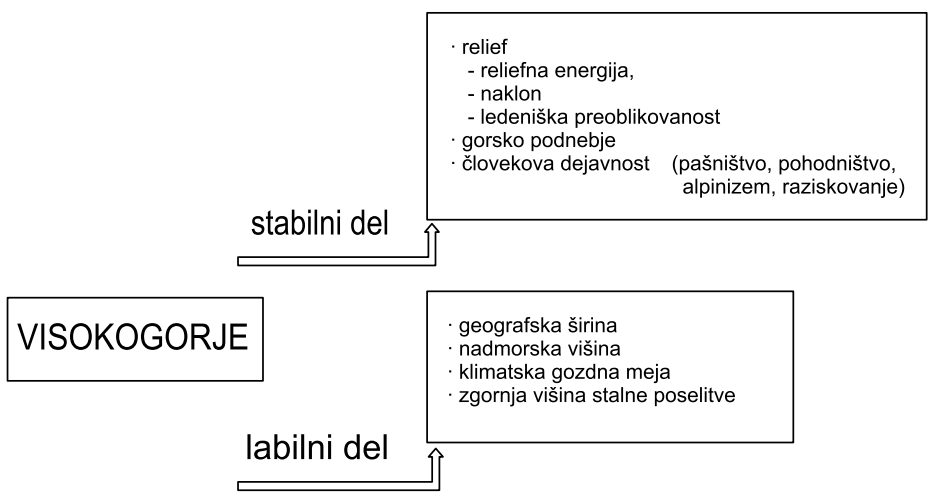

Preučevano območje ledenika Baltoro v pogorju Karakorum (Pakistan) po zgornji definiciji v celoti spada v visokogorje glede na geografske elemente stabilnega dela. Po nadmorski višini sodi med najvišja območja na svetu, z največjo reliefno energijo in nakloni, 
največjo gostoto vrhov, zgornjo klimatsko gozdno mejo nad $3500 \mathrm{~m}$ in zgornjo mejo poselitve nad $3200 \mathrm{~m}$. Območje $57 \mathrm{~km}$ dolgega ledenika v pakistanski provinci Baltistan predstavlja eno najbolj poledenelih in hkrati najvišjih območij na Zemlji, saj ga v začetnem delu obkrožajo 4 vrhovi nad $8000 \mathrm{~m}$, med katerimi je tudi druga najvišja gora na svetu - K2 (8611m). Govorimo lahko o enem izmed najbolj tipičnih visokogorskih območij na svetu. Človek je na tem območju vedno bolj prisoten, saj število obiskovalcev ledenika iz leta v leto narašča.

\section{MOTIVI OBISKOVANJA VISOKOGORSKIH OBMOČIJ}

Visokogorje zaradi svojih naravnogeografskih značilnosti za človeka dolgo časa ni bilo zanimivo, čeprav ga je privlačilo zaradi težke dostopnosti in skrivnostnosti. Motivi prvih raziskovalcev visokogorskih območij po svetu so bili vezani na odkrivanje neznanega, saj so bila tovrstna območja daleč od stalno naseljenih območij. Prve raziskovalce je pritegnila predvsem še nepoznana gospodarska vrednost visokogorskih območij, ki se je v nekaterih primerih pokazala pri bogatih nahajališčih rud in poldragih ter dragih kamnov; pritegnila pa jih je tudi velika nadmorska višina ter nasploh zanimiva gorska narava. V današnjem času je prvotna gospodarska vrednost manj zanimiva predvsem zaradi velikih stroškov veliko ročnega dela, visoki transportni stroški. Visokogorje je postalo zanimivo kot območje preživljanja prostega časa, to pa je prineslo tudi hiter razvoj različnih turističnih dejavnosti in z njimi povezane infrastrukture.

Motive zahajanja $v$ gore danes lahko razvrstimo $v$ več skupin, in sicer: želja po odkrivanju neznanega, novega, strokovno raziskovalni in znanstveni motivi, gospodarski motivi, narodnostni in politični motivi, čustveno romantični ali estetsko hedonistični, zdravstvenohigienski, športno-storilnostni, želja po dogodivščinah, pustolovščinah, želja po potrjevanju, uveljavljanju, želja po kompenzaciji, želja po identifikaciji, beg v samoto ter socialni motivi (Kristan, 1992).

V primeru ledenika Baltoro je glavni motiv za obiskovalce pogled in/ali vzpon na K2 (8611m), ob tem pa tudi želja po doseganju velikih nadmorskih višin bodisi na gori K2 ali na drugih okoliških gorah, mednarodno odmevni športni dosežki, želja po dogodivščini, potrjevanju ter uveljavljanju, deloma tudi želja po identifikaciji. Prav zaradi omogočanja zadovoljevanja različnih motivov ima obiskovanje območja ledenika Baltoro dolgo zgodovino. Obisk se stalno povečuje, na občasna nihanja pa v zadnjih letih vplivajo predvsem svetovni dogodki (npr. 11. september 2001) in notranje politične razmere v Pakistanu. Hkrati s povečevanjem obiska se povečujejo in intenzivirajo tudi negativni okoljski učinki turistične dejavnosti.

\section{TURISTIČNI OBISK OBMOČJA LEDENIKA BALTORO}

Območje ledenika Baltoro spada v pogorje Karakorum, ki se v celoti nahaja v Pakistanu. V dolžini $350 \mathrm{~km}$ se razteza vzporedno s Himalajo, od Siačenskega ledenika na vzhodu, ob meji med Pakistanom in Kitajsko, pa vse do reke Iškamun, ki ločuje Karakorum od pogorja 
Hindukuš na zahodu (Ives, 2004). Razvoj turizma na območju Karakoruma so pogojevale predvsem naravnogeografske razmere, med katerimi velja izpostaviti veliko koncentracijo visokih gora - pet vrhov nad 8000 m: K2 (8611m), Nanga Parbat (8125 m), Gašerbrum I (8063 m), Broad Peak (8047 m) in Gašerbrum II (8035 m) - na relativno majhnem območju. Prav želja po vzponih na najvišje vrhove je v sredini 20. stoletja postala gonilna sila razvoja turizma, ki je bil sprva omejen na raziskovalne in alpinistične odprave, šele precej let kasneje pa je sledil razmah pohodniškega turizma. Izjemen porast obiska je omogočila izgradnja karakorumske »avtoceste« - KKH - Karakorum Highway leta 1978. Število turistov je npr. v dolini Hunza leta 1979 znašalo komaj 302 in se je do leta 1985 povečalo na 5361 (Ives, 2004).

Območje ledenika Baltoro je danes eno najbolj obiskanih visokogorskih območij v Karakorumu in privablja pohodnike, alpiniste, avanturiste in tudi raziskovalce. Geografski položaj ledenika, ki leži v bližini pakistansko-indijske meje, pogojuje nadzorovan obisk, kar pomeni, da so na voljo podatki o letnem obisku območja. Pakistanska planinska zveza beleži podatke o številu alpinističnih odprav in o številu njihovih članov ter o skupinah in številu pohodnikov.

Slika 2: Ledenik Baltoro z gorskima skupinama Payu in Trango.

Figure 2: Baltoro Glacier with Payu and Trango Mountain groups.

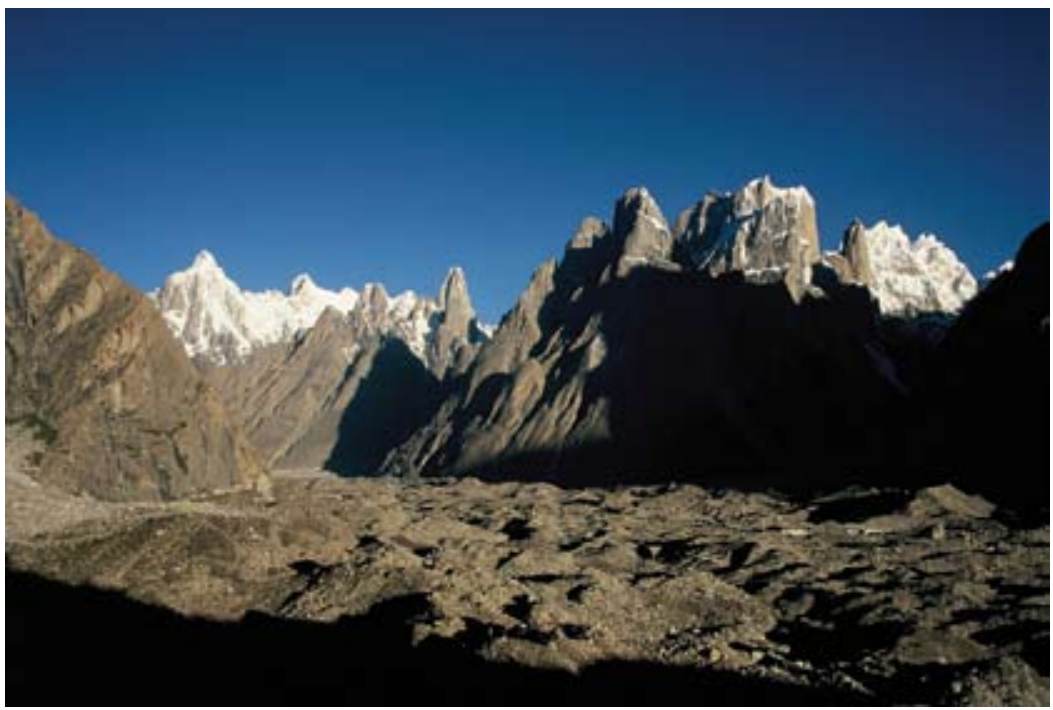

Preučevano območje je najlažje dostopno peš in zahteva od obiskovalcev 12-18 dni aktivne hoje, kar vključuje dostop in prehod preko ledenika, do vznožja posameznih gora ter sestop nazaj na izhodišče. Za tovrstno dejavnost je potrebna pomoč domačinov, ki kot nosači, kuharji in vodniki obiskovalcem pomagajo pri nošenju opreme in hrane. Pri okoljskih učinkih turistične dejavnosti na ledeniku smo tako upoštevali dejansko število obiskovalcev 
ter ocenili število oseb, ki običajno spremljajo posamezne skupine. Njihovo število (nosači, vodniki, kuharji, pomočniki...) je odvisno od velikosti skupine obiskovalcev. Na podlagi podatkov o obiskovalcih ter na podlagi ocen o številu spremljevalcev smo izračunali, koliko ljudi dejansko prehodi ledenik Baltoro v enem letu, kolikšna je povprečna doba bivanja na ledeniku in posledično kakšni so pritiski tovrstne dejavnosti na okoljske sestavine območja (Preglednica 1).

Iz preglednice 1 je razvidno, da se število obiskovalcev v zadnjih letih hitro povečuje predvsem na račun povečevanja števila pohodnikov, medtem ko število alpinističnih odprav narašča nekoliko počasneje. Leta 2003 je bilo število obiskovalcev precej zmanjšano zaradi terorističnega napada na New York leta 2001; dogodek je še nekaj let po tem krojil svetovne turistične tokove, med drugim tudi obiskanost ledenika Baltoro (in muslimanskih držav nasploh). Leta 2004 je na občutno povečanje obiska vplivala 50. obletnica prvega pristopa na K2 (8611m), ki so ga leta 1954 opravili člani italijanske alpinistične odprave. V ta namen je bila organizirana slovesnost $\mathrm{v}$ baznem taboru pod goro, vse poletje pa so zaznamovale številne skupine pohodnikov pretežno iz Italije, ki so z obiskom želeli počastiti to pomembno obletnico. Podatki za leto 2006 izkazujejo stanje, za katerega je značilen vsakoletni porast števila obiskovalcev. Trend se je nadaljeval v letu 2007, notranje politični dogodki v drugi polovici leta 2007 pa bodo verjetno ponovno vplivali na zmanjšan turistični obisk v letu 2008.

Slika 3: Bazni tabori pod osemtisočaki se v poletnih mesecih spremenijo v prava naselja.

Figure 3: Every summer base camps under 8000 m peaks turn into »settlements".

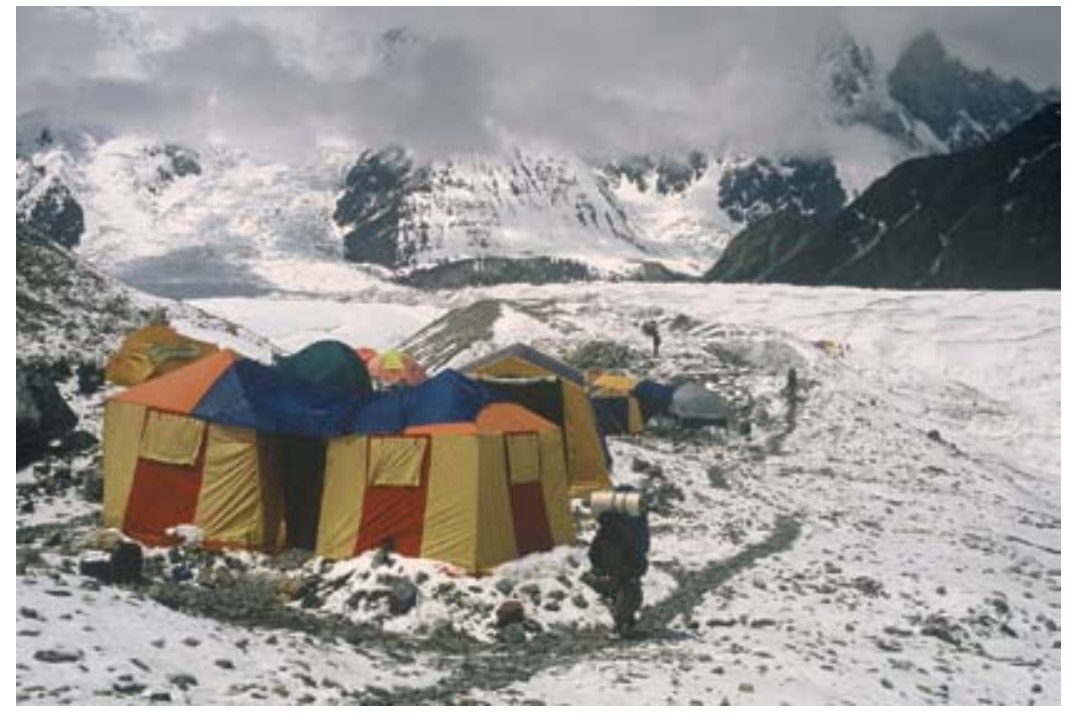


Preglednica 1: Obiskanost ledenika Baltoro leta 2003, 2004 in 2006

Table 1: Number of visitors on the Baltoro Glacier in 2003, 2004 and 2006

\begin{tabular}{|c|c|c|c|c|}
\hline Skupine obiskovalcev & & 2003 & 2004 & 2006 \\
\hline \multirow[t]{2}{*}{ ODPRAVE/VSE (Pakistan) } & št. odprav & 54 & 56 & 87 \\
\hline & št. članov & 466 & 605 & 627 \\
\hline \multirow[t]{3}{*}{ ODPRAVE/BALTORO } & št. odprav & 35 & 37 & 48 \\
\hline & št. članov & 315 & 400 & 420 \\
\hline & št. prehodov Baltora & 630 & 800 & 840 \\
\hline POVPREČNO ŠTEVILO ČLANOV & & 8-9 & $10-11$ & $10-11$ \\
\hline \multirow[t]{2}{*}{$\begin{array}{l}\text { ŠTEVILO NOSAČEV } \\
\text { (povprečno 10/člana odprave do baznega } \\
\text { tabora in povprečno 6/člana odprave na } \\
\text { poti nazaj) }\end{array}$} & & 5040 & 6400 & 6720 \\
\hline & št. prehodov Baltora & 10080 & 12800 & 13440 \\
\hline \multirow[t]{2}{*}{$\begin{array}{l}\text { KUHARJI, VIŠINSKI NOSAČI, } \\
\text { VODNIKI... } \\
\text { povprečno 5/odpravo }\end{array}$} & & 175 & 185 & 240 \\
\hline & št. prehodov Baltora & 350 & 370 & 480 \\
\hline $\begin{array}{l}\text { PREHODI BALTORA -skupaj } \\
\text { ODPRAVE }\end{array}$ & & 11060 & 13970 & 14760 \\
\hline \multirow[t]{2}{*}{ ŠTEVILO POHODNIKOV } & & 377 & 1721 & 2445 \\
\hline & št. prehodov Baltora & 754 & 3442 & 4890 \\
\hline \multirow[t]{2}{*}{$\begin{array}{l}\text { ŠTEVILO NOSAČEV } \\
\text { (povprečno } 4 \text { /pohodnika, vključno s } \\
\text { kuharji in vodniki) }\end{array}$} & & 1508 & 6884 & 9780 \\
\hline & št. prehodov Baltora & 3016 & 13768 & 19560 \\
\hline $\begin{array}{l}\text { PREHODI BALTORA -skupaj } \\
\text { (POHODNIKI) }\end{array}$ & & 3770 & 17210 & 24450 \\
\hline PREHODI BALTORA -skupaj VSI & & 14830 & 31180 & 39210 \\
\hline
\end{tabular}

VIR: Alpine Club of Pakistan; Islamabad, 2006; ocene in izračuni I. Mrak.

\section{UGOTAVLJANJE ONESNAŽENOSTI OBMOČJA LEDENIKA BALTORO}

S terenskim delom septembra 2006 in v juliju in avgustu 2007 smo želeli ugotoviti okoljske pritiske in učinke množičnega visokogorskega turizma ter s posrednimi metodami dokazati povezanost turistične dejavnosti z dejanskim poslabšanim stanjem posameznih naravnogeografskih elementov $\mathrm{v}$ pokrajini. 
Slika 4: Organski odpadki v baznem taboru pod Broad Peakom (n.v. 5000m).

Figure 4: Organic waste in the Broad Peak Base Camp (5000m a.s.l.)

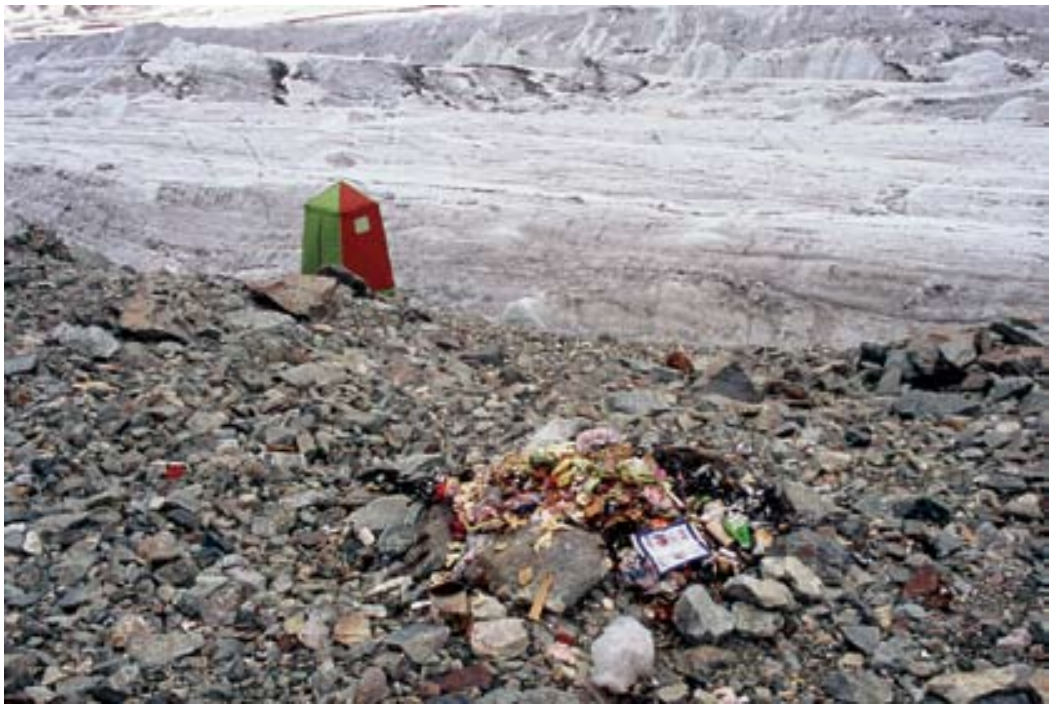

Slika 5: Anorganski odpadki v pohodniškem kampu Johla (n.v. 3200m)

Figure 5: Anorganic waste in the trekking camp Johla (3200m a.s.l.)

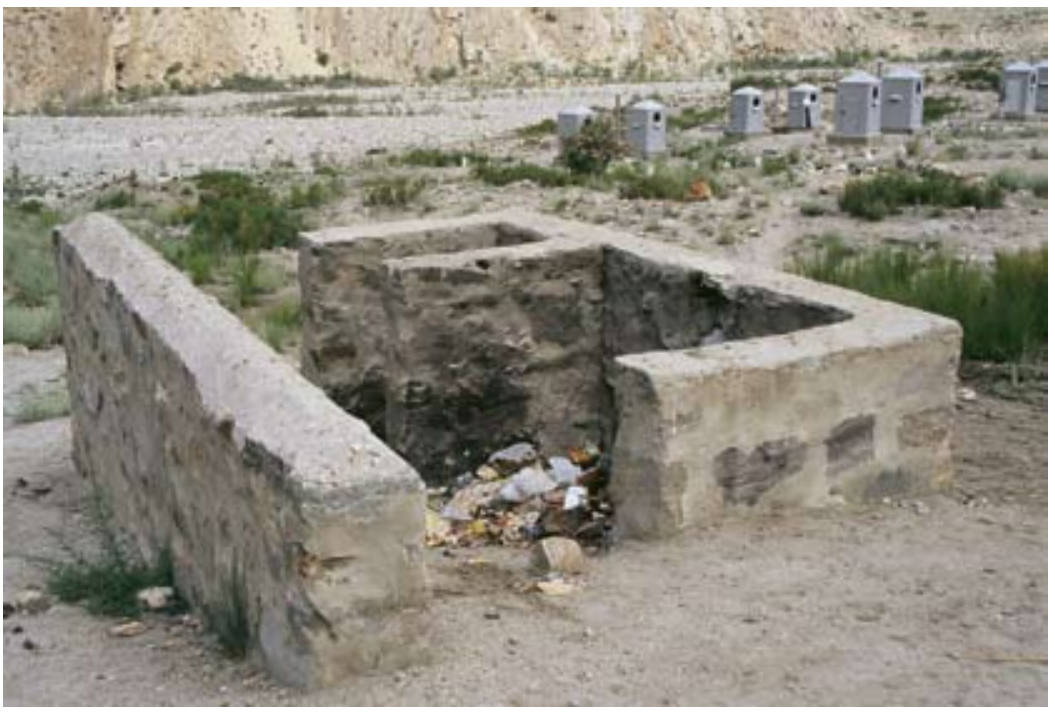

Na planinskih poteh ter v pohodniških kampih in baznih taborih na območju ledenika smo ugotavljali pritiske, ki so posledica množičnega obiska. Med glavne pritiske tako uvrščamo povečevanje količin organskih odpadkov (človeško in živalsko blato in urin, živalska 
in človeška trupla, ostanki hrane), anorganske odpadke (plastenke, pločevinke, kovinske in lesene škatle, plinske bombice, ostanki opreme - šotori, spalne vreče, vrvi...), povečevanje hrupnega onesnaževanja (obiskovalci, helikopterski preleti) ter kurjenje in izlitja kerozina.

Učinki pritiskov se kažejo v poslabšanem stanju posameznih naravnogeografskih prvin pokrajine. Na terenu smo dve leti zapored z enostavnimi testi lastnosti vode na 16 merilnih mestih ugotavljali vsebnost nitratov, fosfatov, amonija, kisika ter vrednost $\mathrm{pH}$. Lokacije so bile izbrane vzdolž ledenika, in sicer v vseh pohodniških kampih in glavnih baznih taborih ter na nekaterih vmesnih lokacijah ob glavni poti preko ledenika. Kampi predstavljajo »vroče« točke onesnaževanja, obseg in intenzivnost pa se povečujeta v smeri proti najvišjim baznim taborom - torej od konca ledenika proti rediščnemu delu. Pri analizah lastnosti vode smo ugotovili, da fosfati nikjer niso bili prisotni, tudi vrednosti amonija so bile zelo nizke. Pri vsebnosti kisika (v mg/l) so bile najnižje vrednosti ugotovljene na območju Concordije in baznega tabora pod Broad Peakom. V obeh primerih gre za najbolj obljudena kampa, kjer je velika koncentracija pohodnikov, nosačev in tovornih živali od meseca maja, do konca septembra. Vrednosti nitratov so bile najvišje v glavnem ledeniškem potoku na koncu ledenika. Enako visoke vrednosti $(5 \mathrm{mg} / \mathrm{l})$ so bile dvakrat na isti lokaciji izmerjene tudi v letu 2007, kar kaže na to, da se s površinskimi vodami organske snovi izpirajo skozi telo ledenika do podledeniškega potoka, ki ima manjše samočistilne sposobnosti kot površinski potoki. Prisotnost nitratov je posledica velikih količin organskih odpadkov, ki izhajajo iz množičnega obiska, hkrati del nitratov po vsej verjetnosti pride v vodo iz zraka, viri onesnaženja pa so lahko nekaj $100 \mathrm{~km}$ daleč stran.

Učinki pritiskov na ostale naravnogeografske elemente so na preučevanem območju težje merljivi in jih lahko zgolj ocenjujemo. Helikopterski preleti in z njimi povezano hrupno onesnaževanje so pogosti v primeru nesreč in oskrbovanja vojaških postojank vzdolž ledenika. Vojaške postojanke predstavljajo stalne vire onesnaževanja, saj so obljudene preko celega leta, vendar so podatki o številu vojakov zaupne narave. Ekološko stanje na območju vojaških postojank je precej slabše kot v turističnih kampih, tako lahko trdimo, da tudi vojska prispeva k onesnaževanju ledenika, v kakšnem obsegu pa zaenkrat ni mogoče oceniti.

Negativni vpliv na vegetacijo je bil močno prisoten vse do konca devetdesetih let 20 . stoletja. Nosači so na poti do ledenika in na stranskih pobočjih ob ledeniku sekali gr-mičevje za potrebe pripravljanja hrane. V nekaj desetletjih so grmičevje skoraj v celoti izse-kali, zato je bila v začetku 21. stoletja uvedena obvezna uporaba kerozina, kar je omejilo izsekavanje. Nosači so kerozin na začetku zavračali, saj nima enakega »domačega« učinka, kot naravni ogenj, danes pa je v vsesplošni uporabi, čeprav je sekanje grmičevja občasno še vedno prisotno. Kerozin tako predstavlja enega od potencialnih pritiskov na vode in ledenik nasploh, ob morebitnih izlitjih, ki pa se dogajajo zlasti ob koncu odprav in nasploh turistične sezone, ko večina odprav preostali kerozin zlije v ledeniške razpoke ali pa ga zažge, saj se jim transport nazaj v dolino zaradi visokih stroškov (plačilo nosačev) ne splača. Med dolgoročnimi učinki pritiskov tako lahko izpostavimo predvsem zmanjševanje privlačnosti območja ter posledično zmanjševanje obiska.

Za ledenik smo izdelali klasični DPSIR model, v katerem predstavljamo aktualno okoljsko stanje Baltora. 
Slika 6: Rezultati terenskega preučevanja - september 2006.

Figure 6: The field work results - september 2006.

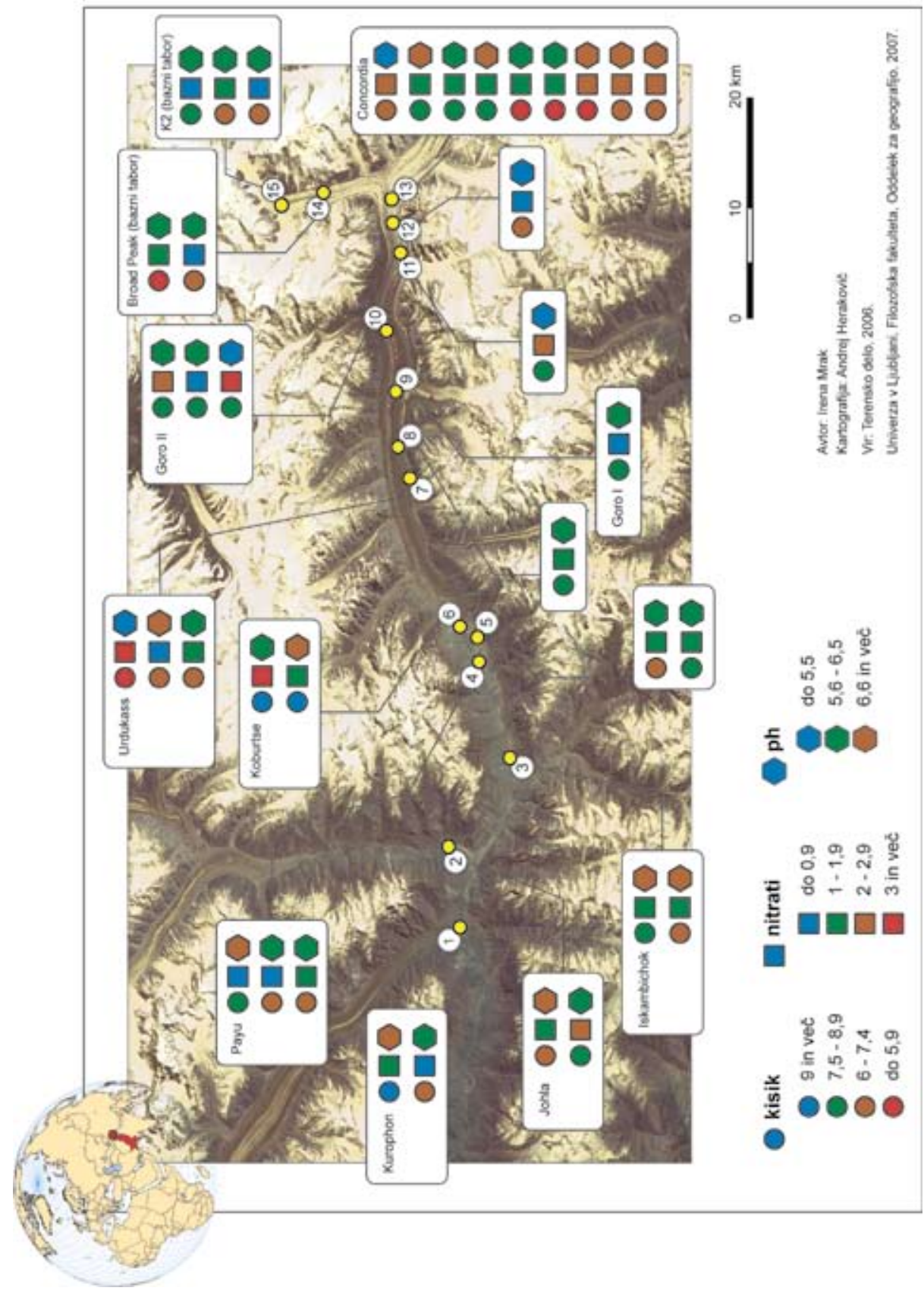


Slika 7: DPSIR model za ledenik Baltoro

Figure 7: DPSIR model for Baltoro Glacier

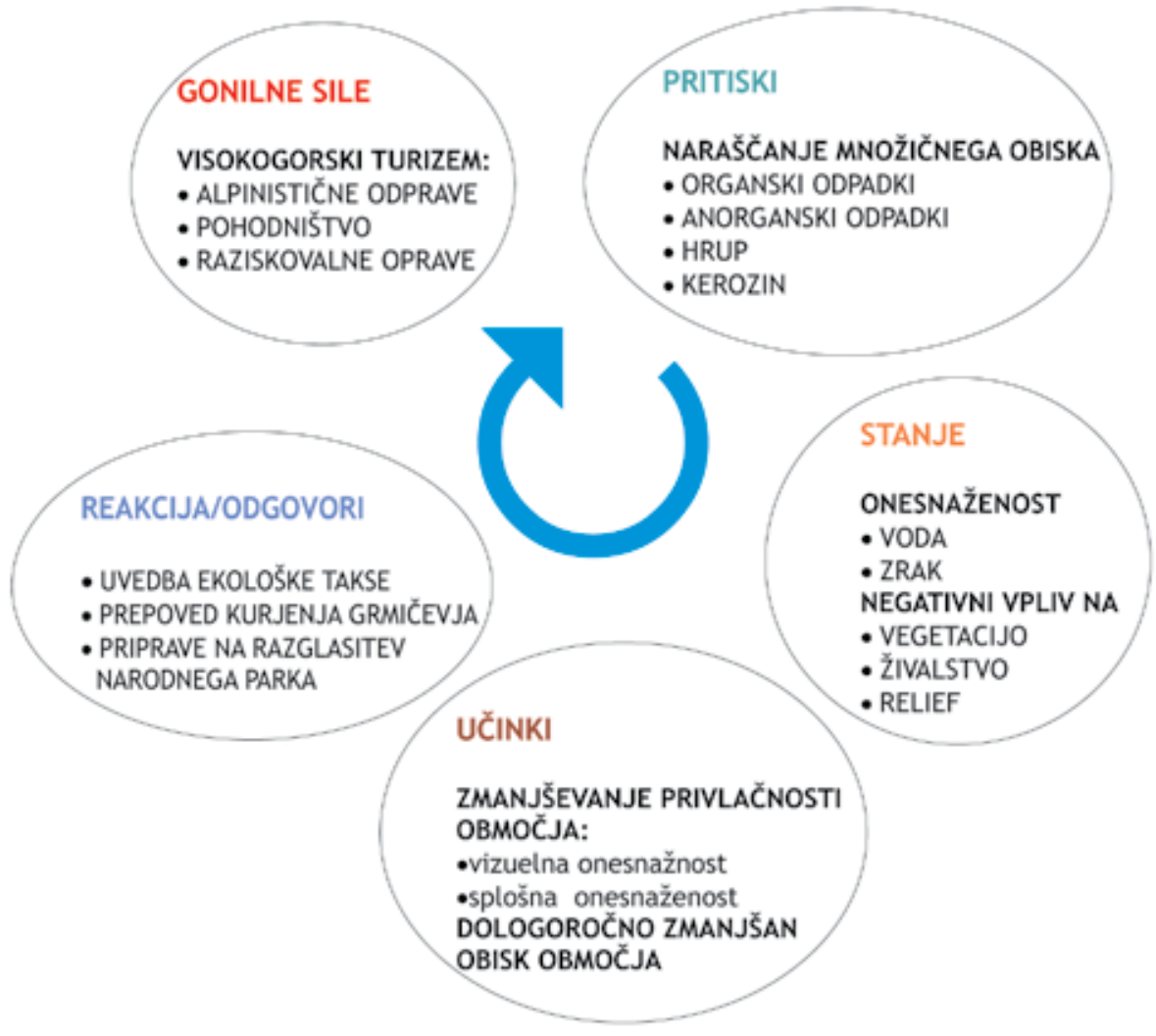

\section{OKOLJSKO STANJE POKRAJINSKO-EKOLOŠKIH ENOT OBMOČJA LEDENIKA BALTORO}

Znotraj območja ledenika Baltoro so pritiski in učinki turistične dejavnosti različno prisotni. Glede na naravnogeografske značilnosti smo določili 3 pokrajinskoekološke enote. Zunanjo mejo celotnega območja ledenika predstavlja razvodnica reke Biaho (povirni del), znotraj pa smo določili 3 pokrajinsko-ekološka območja, in sicer na podlagi nadmorske višine in reliefnih oblik:

1. ledenik Baltoro: do nadmorske višine 5200 m: pohodniški kampi, 3 bazni tabori,

2. stranski ledeniki: do nadmorske višine $6200 \mathrm{~m}$ : 1 bazni tabor, 1 pohodniški kamp,

3. pobočja: nad glavnim in stranskimi ledeniki do višine nadmorske višine $8600 \mathrm{~m}$. 
Slika 8: Pokrajinskoekološke enote območja ledenika Baltoro

Figure 8: Ecological Landscape units of Baltoro Glacier

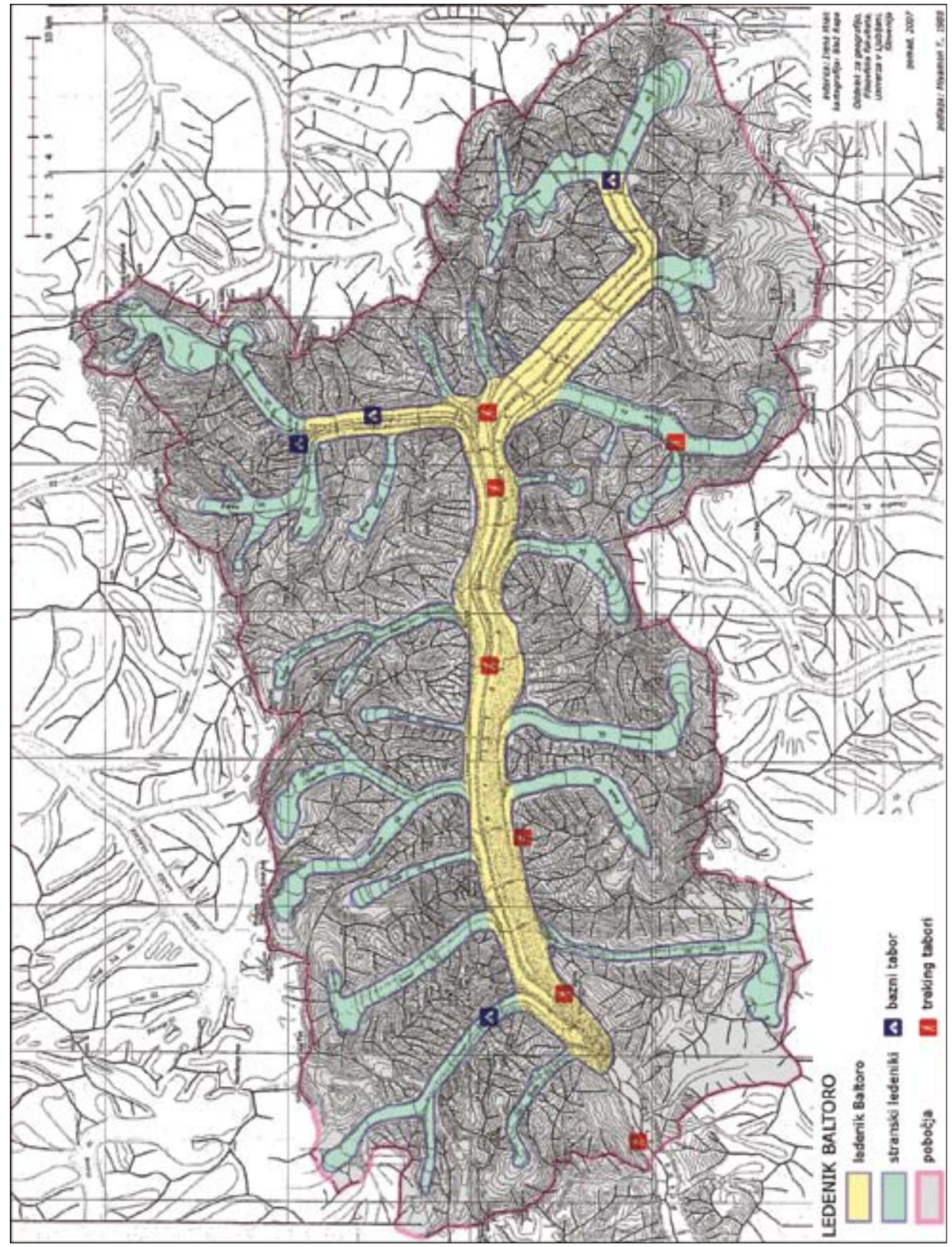


Ledenik Baltoro s $125 \mathrm{~km}^{2}$ predstavlja dobrih $10 \%$ celotnega območja. Tu gre za največjo koncentracijo pohodniških kampov in baznih taborov, zato je tudi stopnja onesnaženosti te pokrajinsko ekološke enote v primerjavi z ostalima dvema največja. Stranski ledeniki predstavljajo $195 \mathrm{~km}^{2}$ ali $15 \%$ celotnega območja, pobočja pa so s $982 \mathrm{~km}^{2}$ ali $75 \%$ najobsežnejša pokrajinskoekološka enota.

Okoljski pritiski množičnega visokogorskega turizma so po posameznih enotah različni, kar pogojuje predvsem različna dolžina obiska posamezne enote. Obisk je najdaljši na ledeniku Baltoro, kjer so tudi pritiski najbolj obsežni in hkrati najbolj intenzivni. Obisk stranskih ledenikov in pobočjih je mnogo krajši, hkrati je manjše tudi število obiskovalcev (v prvi vrsti so to plezalci), tako je tudi stopnja onesnaženosti mnogo manjša, vendar pa zaradi večjih nadmorskih višin ne nezanemarljiva, saj so samočistilne sposobnosti teh območij v primerjavi z glavnim ledenikom manjše.

Za leto 2006 smo izračunali količine človeškega blata in urina, ki so ostale po posameznih pokrajinskoekoloških enotah, za izračun pa smo upoštevali dnevne vrednosti ( $200 \mathrm{~g}$ blata in 1150 g urina/osebo/dan (Gotaas, 1956). Tako je v letu 2006 je na območju ledenika Baltoro ostalo 50 t človeških iztrebkov in $282 \mathrm{t}$ urina, na območju stranskih ledenikov $0,18 \mathrm{t}$ človeških iztrebkov in $1,1 \mathrm{t}$ urina, na območju pobočij pa $1,3 \mathrm{t}$ človeških iztrebkov in $7,6 \mathrm{t}$ urina. $\mathrm{Na}$ celotnem območju Baltora je tako ostalo 51 t človeških iztrebkov in $291 \mathrm{t}$ urina. Na podlagi povprečnih vrednosti hranil smo izračunali količine dušika, fosforja in kalija, ki so v letu 2006 ostale na obravnavanem območju (Preglednica 2).

Preglednica 2: Vrednosti izračunanih hranil na območju Baltora v letu 2006 Table 2: The fertilizer amounts in the area of Baltoro Glacier in 2006

\begin{tabular}{|l|c|c|c|c|c|c|}
\hline & $\mathrm{N}(\mathrm{kg})$ & $\mathrm{N} / \mathrm{km}^{2}$ & $\mathrm{P}(\mathrm{kg})$ & $\mathrm{P} / \mathrm{km}^{2}$ & $\mathrm{~K}(\mathrm{~kg})$ & $\mathrm{K} / \mathrm{km}^{2}$ \\
\hline ledenik Baltoro & 3577 & $28 \mathrm{~kg} / \mathrm{km}^{2}$ & 377 & $3 \mathrm{~kg} / \mathrm{km}^{2}$ & 753 & $6 \mathrm{~kg} / \mathrm{km}$ \\
\hline stranski ledeniki & 14 & $0,07 \mathrm{~kg} / \mathrm{km}^{2}$ & 1,5 & $0,008 \mathrm{~kg} / \mathrm{km}^{2}$ & 3 & $0,015 \mathrm{~kg} / \mathrm{km}^{2}$ \\
\hline pobočja & 96 & $0,09 \mathrm{~kg} / \mathrm{km}^{2}$ & 10 & $0,01 \mathrm{~kg} / \mathrm{km}^{2}$ & 20 & $0,02 \mathrm{~kg} / \mathrm{km}^{2}$ \\
\hline skupaj & 3692 & $2,8 \mathrm{~kg} / \mathrm{km}^{2}$ & 389 & $0,3 \mathrm{~kg} / \mathrm{km}^{2}$ & 777 & $0,6 \mathrm{~kg} / \mathrm{km}^{2}$ \\
\hline
\end{tabular}

Izračunane vrednosti kažejo na največjo obremenjenost ledenika Baltoro in najmanjšo obremenjenostpobočij,kisoprostorskonajvečjainhkratinajmanjobiskanapokrajinskoekološka enota. Regeneracijske in nevtralizacijske sposobnosti območja so na splošno nizke, vendar pa $\mathrm{v}$ primeru pobočij in stranskih ledenikov turizem še ne vpliva negativno na kvaliteto vode. Bolj problematično je stanje glavnega ledenika, kjer se kaže, da imajo površinski vodotoki visoke samočistilne sposobnosti, ki pa se zmanjšujejo v smeri proti podledeniškemu potoku. Le-ta je v vseh treh merjenjih vsebnosti nitratov izkazal največje vrednosti.

\section{SKLEP}

Množičnost obiska na območju ledenika Baltoro se povečuje od sredine 20. stoletja dalje in je sicer odvisna od svetovnih in notranje političnih dogodkov, vendar pa že resno ogroža 
naravnogeografske elemente na obravnavanem območju. S terenskim delom ugotovljeni pritiski in učinki kažejo na to, da turizem kot dejavnost negativno vpliva predvsem na kvaliteto vode. Kljub veliki intenzivnosti vplivov v zgornjem rediščnem delu ledenika, se učinki na kvaliteto vode najbolj odražajo v spodnjem delu ledenika. Stranski ledeniki in pobočja zaenkrat še ne izkazujejo negativnega vpliva na vode. Onesnaževanje ledenika je točkovno in skoncentrirano v pohodniških kampih in baznih taborih, ki predstavljajo »vroče« točke onesnaževanja. Na teh mestih so najbolj očitni vsi negativni vplivi in učinki turizma - npr. velike količine organskih in anorganskih odpadkov, posekano grmičevje, erozija poti, hrup idr. Vzdolž poti preko ledenika so negativni učinki turizma minimalni, vezani zgolj na ozek pas ob poti, kjer se občasno pojavljajo živalska trupla in anorganski odpadki. Izračunane vrednosti hranil, ki so v letu 2006 ostale na obravnavanem območju, kažejo na veliko obremenjenost glavnega ledenika, ki zato že izgublja privlačnost za obiskovalce. Kljub temu pa je v prihodnosti mogoče pričakovati nadaljnji trend povečevanja obiska, saj so motivi obiska ne glede na kritično ekološko stanje območja veliki. Za ceno pogleda na drugo najvišjo goro sveta so obiskovalci pripravljeni sprejemati tudi takšno situacijo, čeprav so do nje kritični in v prihodnosti lahko preraste $\mathrm{v}$ omejitveni dejavnik za razvoj turizma tega območja.

Visokogorski turizem doživlja izjemen razmah $\mathrm{v} v$ vseh svetovnih gorstvih in $\mathrm{s}$ svojimi značilnostmi predstavlja okoljsko grožnjo območjem, kjer so procesi vse do nedavnega potekali brez prisotnosti človeka. Zgolj nadzorovan obisk in pa visoka zavest obiskovalcev pa predstavljata garancijo za sonaravni in hkrati trajnostni razvoj turizma v visokogorju.

\section{Literatura}

Boyd, S.W., 2000. Tourism, National Parks and Sustainability. Tourism and National Parks. Issues and Implications.

Cvitanović, A., 2002. Geografski riječnik. Hrvatsko geografsko društvo Zadar.

Gotaas, H., 1956. Composting: Sanitary Disposal and Reclamation of Organic Wastes. World Health Organization, Geneva.

Goudie, A., 2006. The Human Impact on the Natural Environment (Past, Present and Future). Blackwell Publishing

Hall, M.C., Lew, A.A., 1998. Sustainable tourism. A Geographical Perspective. Addison Wesley Longman Limited.

Ives, J., 2004. The Himalayan Perceptions. Environmental change and the well-being of the mountain peoples. Routledge.

Kladnik et al., 2005. Geografski terminološki slovar. Ljubljana, Založba ZRC.

Kristan, S., 1992. Motivi za hojo v gore - pomemben vzgojni dejavnik. Šport, 40(3), str.12-17.

Müller, H., 2004. Turizam i ekologija. Masmedia, Zagreb (prevod Jasenka Kosanović). Newsome, D., et al., 2002. Natural area tourism. Ecology, Impacts and Management. Channel View Publications.

Swarbrooke J, et al., 2003. Adventure Tourism. The new frontier. Elsevier Science Ltd.

Špes et al., 2002. Študija ranljivosti okolja (metodologija in aplikacija), Geographica Slovenica 35, 1-2. Založba ZRC, Ljubljana. 
Wong, P.P., 2004. Environmental Impacts of Tourism. A Companion to Tourism (pages 450 461). Blackwell Companions to Tourism.

Zurick, D., Pacheco, J., 2006. Illustrated Atlas of the Himalaya. The University Press of Kentucky.

Viri

UNEP, 2007. http://www.uneptie.org/pc/tourism/sust-tourism/env-3main.htm (citirano 25.11.2007)

\section{POLLUTION ON THE BALTORO GLACIER AS A CONSEQUENCE OF TOURISM}

\section{Summary}

Due to specific geographic conditions, the high mountain areas were unsettled for a long time, with infrequent human visits.. The economic use of such areas was mostly connected to mining and alpine pasturing. The development of mountain tourism paralleled the increase of an individual's spare time, as well as the easing of access to the high mountain areas. Tourism development has created human impact in high mountain areas to the point of being easily visible and disturbing. Environmental pressures and impacts of mountain tourism are very complex, as they pollute the main environmental elements (relief, soil, water, air) as well as negatively impacting natural flora and fauna.

A unique definition of all high mountain areas of the world is difficult to create due to varying geographic characteristics, yet components of a definition can be identified. The so called stable part of the definition is composed of physical-geographic factors typical for the high altitude areas (relief, high mountain climate) and of human activities that are present in these areas (pasturing, trekking, climbing and research activities). The so called labile part of the definition is what points out the differences among the world's high mountain areas; consisting of geographic location, altitude, upper climate forest line and the permanent settlement altitude. The Baltoro Glacier study area in the Karakorum Mountains is one of the most typical high mountain areas due to its very high relief energy, steep inclinations, the mountain summit density, the upper climate forest line at $3500 \mathrm{~m}$ a.s.l. and the permanent settlement altitude at $3200 \mathrm{~m}$ a.s.l. The $57 \mathrm{~km}$ long glacier is a part of one of the most glaciated areas in the World and in its upper part encircled by four summits higher than $8000 \mathrm{~m}$, among them being the second highest mountain $-\mathrm{K} 2(8611 \mathrm{~m})$. From the mid $20^{\text {th }}$ century, the human presence in the area has intensified due to tourism activities in the summer months. Tourism represents one of the most important sources of revenue for the local population in Shigar Valley, as well as the overall province of Baltistan. The royalty peak fees importantly add to the state budget of Pakistan.

The Baltoro Glacier visitors' main motive is to get a view of $\mathrm{K} 2$, as well as the surrounding peaks, or the opportunity to ascend these mountains. The other motives are also an adventure experience, self confirmation as well as in some cases the internationally important sporting achievement. The geographic position of the glacier, near the Indian-Pakistani border, means the Government of Pakistan, via the Alpine Club of Pakistan, keeps annual 
records of all visitors to the region. On the basis of this data and with the estimation of the accompanying persons (porters, cooks, guides, etc.) of the expedition and trekking groups we have calculated the actual Baltoro Glacier crossings and the number of days that people stay in the area. The calculations were crucial in estimating the actual tourism environmental impact on the glacier.

The field work in September 2006 and summer 2007 was dedicated to the identification of environmental pressures and impacts of the high mountain mass tourism. Through the indirect method (the simple water characteristic tests) and other observations we discovered the actual link of tourism activities in the area with the actual deterioration of individual physical geographic elements in the area. The main pressures identified were: organic waste (human and animal excreta, animal and human bodies, the food waste), inorganic waste (plastic bottles, tin cans, tin and wooden boxes, gas cartridges, remains of trekking and climbing equipment - tents, sleeping bags, ropes...), noise pollution (helicopter flights, visitors) as well as the kerosene burnt and spilt.

Water sampling and tourism impact observation locations were chosen along the glacier - in all trekking routes and mountain base camps, as well as, glacial side streams and in the main glacier river. Throughout the field-work it has become clear that the trekking routes and mountain base camps represent the pollution "hot" spots. The overall environmental condition in camps deteriorates further along the glacier but the water quality deteriorates in the opposite direction.

In the long-run, the Baltoro Glacier can loose its attractiveness and that can consequently lead to the reduced visits to the area.

Within the wider Baltoro Glacier area the tourism pressures and impacts vary. According to the physical geographic characteristics, 3 main landscape ecological units were defined: the main Baltoro Glacier, side glaciers and slopes. The main Baltoro Glacier represents 10\% of the study area $\left(125 \mathrm{~km}^{2}\right)$. Here the concentration of trekking and base camps is the highest and so is the pollution rate, in comparison to the other two landscape ecological units. The side glaciers cover $15 \%$ of the study area $\left(195 \mathrm{~km}^{2}\right)$ and the largest landscape ecological unit is the slope area, which cover $982 \mathrm{~km}^{2}$ or $75 \%$ of the entire study area. The environmental pressures of high mountain tourism, in the three areas, are differentiated by length of visit. The longest length of stay typically occurs along the main Baltoro Glacier and therefore the tourism impact is most evident. The side glaciers and slopes are visited by smaller numbers of people and also the length of stay there is shorter; therefore the pollution rate is negligible due to the self -purifying capabilities of the environment. 